\title{
MRS. VETERINARY DOCTOR SUHARKO \\ (Nyonya Dokterhewan Suharko)
}

by Pramoedya Ananta Toer

Translated by Benedict Anderson

\section{Translator's Foreword}

My purpose in preparing this translation of Nyonya Dokterhewan Suharko is to do honor to two men, the late John Echols and Pramoedya Ananta Toer, who, in very different, but connected ways, have profoundly affected my relationship to, and thinking about, modern Indonesia.

Though almost a quarter of a century has passed since I first came to Cornell University, I still remember very well the odd mixture of uneasy exhilaration and comfortable familiarity that I felt in plunging into Indonesian under John Echols' tutorship. The exhilaration came from the novelty of what I used to think of as a very American approach to language-teaching--a heavy emphasis on developing oral fluency for the purpose of immediate and practical communication. Sitting in a classroom with government officials, missionaries, and a performing artist or two, all of whom intended to use Indonesian, was a new and exciting experience for a youngster trained, European-style, to think of languages primarily as written repositories of ancient civilizations. I remember thinking ruefully that although I had studied Latin and Greek for twelve years or more, and could even compose bad poetry in both, I was incapable of uttering three consecutive, spontaneous sentences in either.

But John Echols was also a "classicist" in his own way. He wanted his students to be able to use everyday Indonesian with fluency, but, unlike too many of his fellow-linguists in America, he regarded language and literature as inseparably tied to one another. The literature of each language represented its profoundest possibilities. It was, for him, impossible to gain real insight into a society without being familiar with the products of its imagination. So, for a European student like myself, John provided the familiar pleasures of studying a language, not merely by reading its literature, but also by attempting to translate it. For it is only in the immense slowness of the translation process that one learns to taste words, styles, and silences.

It was John's practice, when a student of Indonesian had reached a "dog-paddling" stage of fluency, to encourage him or her to prepare translations of short pieces of Indonesian fiction: not merely as "exercises," but to help open up the terra incognita of modern Indonesian literature to the English-speaking West. Some of the translations he used for the course on Southeast Asian Literature in Translation that he taught for many years at Cornell; others he arranged to be published in various formats. It is essential to remember today that he was responsible for the very first English-language translations of Indonesian literature to appear anywhere. In 1956, he put out Indonesian Writing in Translation (Cornell Modern 
Indonesia Project Translation Series), which included, aside from some poetry, fifteen pieces of prose fiction--among them two texts by Pramoedya Ananta Toer. His co-contributors consisted almost entirely of his current and former students. And that same year he helped compile the Supplement of the Atlantic Monthly called "Perspective of Indonesia" which for the first time brought a glimpse of the rapidly changing culture of postindependence Indonesia to a broad American public.

In this endeavor there was always what I think of as a mixture of John's personal modesty and a sober American practicality. He did not agonize over the "untranslatability" of literatures; it was important to get on with building bridges between languages and cultures while remembering just how rickety these bridges would always be. I recall only too well the intense mortification I felt when I realized that I had completely mistranslated the very title of a story by Achdiat Kartamihardja which John had encouraged me to prepare and which saw the irretrievable light of day in A Treasury of Modern Asian Stories, ed. Daniel Milton (1961). How could I have misread Sensasi diatas pohon kelapa as "Sensations [i.e., feelings] at the top of a coconut tree" (rather than "Sensation [i.e., newspaper sensation] at the top of a coconut tree")? John was amused by this--since he rightly saw that much less damage was done to the English-language readers than to the translator's vanity. From him, I learned the simple truth that the translator has to try his best, but without illusions, to further the best interests of authors and readers; acting, ideally, with the disinterested mediativeness of a good dictionary .

It was through John that I first made my acquaintance, in the silent world of print, with Pramoedya Ananta Toer. John had made it his business, on his quite frequent visits to Indonesia in the 1950 s, to meet as many of the young country's literary figures as he could. He was extremely interested in what was currently being written. It may come as something of a shock today to reflect that many of the items translated in Indonesian Writing in Translation were brand new, i.e., had been written in the previous ten years. He did not at all share the common prejudice that novels are somehow "more serious" than other forms of prose fiction. If some Indonesian critics claimed that Indonesian writers "bernafas pendek" (were short of breath), because they wrote short stories and novellas rather than novels, John was happy to take each work on its own merits and judge it by the form it represented.

In the case of Pramoedya, we students were introduced to the famous novels of the early 1950s, Keluarga Gerilya above all, but also Perburuan, Korupsi, and others. Yet I believe I am right in thinking that John was fondest of the wonderful short stories contained in Cerita dari Blora. From him we students learned to appreciate them, and then, as is the nature of pupils, decide eventually we had tastes of our own.

"Nyonya Dokterhewan Suharko" comes from Cerita dari Jakarta, Sekumpulan Karikatur Keadaan dan Manusianya [Tales of Jakarta, a Collection of Caricatures of Conditions and Their Human Beings] published in 1957. Though (I would be ready to argue) the quality of this collection is on a par with that of Blora, none of the tales in it has yet been translated into English. This neglect has, I think, two causes. The stories in Blora mostly deal with episodes in Pramoedya's own young life, or with the great catastrophes of the Japanese occupation and the Revolution. They have on the whole a romantic and tragic feel about them, which allows them to be readily assimilated to the drama of Indonesia's liberation from colonial rule. Most of the tales in Jakarta, however, are meditations on the unpleasant realities of postindependence Indonesian society; many are composed in a deliberately fantastic, sardonic ("karikatur") vain, which perhaps makes them less than immediately likeable. In the second place, by the time Jakarta was published Pramoedya himself was beginning to become active in leftwing politics; and it was an article of faith 
for many liberal literary critics of that period that "political activism" meant "worse literature." It was perhaps easy therefore to marginalize Jakarta for extraneous political reasons.

The irony of all this is that today Jakarta threatens to be marginalized for a very different reason. When I wrote to Pramoedya asking his permission to translate "Nyonya Dokterhewan Suharko," he responded that "Frankly speaking, I never [re-] read 'Nyonya Dokterhewan Suharko' either before or after it was printed in Cerita dari Jakarta. When forced [by your request and questions] to read it again, the text was extremely strange [alien?] for me [sudah sangat asing bagi saya]." If the author himself now finds the story "strange," how much less likely it is that others will pay attention to it. In addition, the extraordinary heroism of Pramoedya's life since 1965--the years of incarceration as a political prisoner, and the production of a stream of major literary works while under detention--is apt further to concentrate attention on either the "late" or the "early" writings. And this tendency is all the more likely in that, in some respects, Bumi Manusia and Anak Semua Bangsa are strongly reminiscent of Blora.

In any event, I feel it is time to underline Pramoedya-the-stylist, alongside Pramoedya-the-story-teller, Pramoedya-the-moralist, and other familiar Pramoedyas. Insofar as "Nyonya Dokterhewan Suharko" is not "about" the colonial period or the Revolution, the injured or the insulted, Pramoedya himself or his family, it may allow the reader more freedom to savor the way Pramoedya writes, his literary dexterity, his fantasy, his way of posing the problem of writing, and, not least, his humor.

Finally, since Pramoedya was gracious enough to reply in detail to my questions about interpretation and translation, I think it is valuable to append some of these comments, in the original Indonesian, in footnotes. 


\title{
MRS. VETERINARY DOCTOR SUHARKO ${ }^{1}$
}

\author{
Pramoedya Ananta Toer
}

One day, a friend of mine invited me to go with him to take a look at a 1952model 150-cc. Express motorcycle that he wanted to buy off a friend of his. "Come help me check it out," he said. So the two of us set off for the friend's house. The motorcycle seemed still in good condition, and the price wasn't bad either-5,000 rupiah.

When the paper work had been completed, my friend's friend said: "Watch out! In the next few days you'll be getting a visit from Mrs. Veterinary Doctor Suharko!"

"What about?"

"This motorcycle. Have you really never heard that terrific name? She'll come around and ask you for it. She'll sign an IOU, and ask you for a bill of transfer. It used to be hers. But be sure you don't do as she asks."

"Why does she have to ask for it back and sign me an IOU?"

"It's like this. You'll never get the motorcycle back, and she'll never deliver on the IOU." And with evident pleasure my friend's friend began his story:

"I know Veterinary Doctor Suharko. He's got three kids. The eldest, Jan, is now eighteen. Next year, he'll be enrolling at the Faculty of Economics. There's no need to mention the others, as they're not important in this story of this 150-cc. Express.

Some months after completing his studies, Suharko opened his own practice. It turned out that he dearly loved his work as a veterinarian. In return, his work brought him many rewards, many passions, many loves, and many other pleasures. Within six months he'd become the veterinarian for five out-of-town dairies and a dogbreeding business--all of them owned by foreigners. One of these enterprises provided him with a portion ${ }^{2}$ of unsullied love from a young Eurasian girl, the offspring

1. For a number of reasons, the Indonesian title of this story--Nyonya Dokterhewan Suharko--is impossible to translate satisfactorily into English. Indonesian follows the Dutch (and Continental) practice, whereby the wife of a professional is addressed by her husband's title(s). "Mrs. Veterinary Doctor Suharko" is, however, completely unidiomatic English. It is not possible to paraphrase the title as "The wife of Dr. Suharko" or "The wives of Dr. Suharko" because the Indonesian focuses on a single title (held consecutively by two women), rather than one or both of their persons. One can retain the formal professionalism of Dokterhewan in "Veterinary Doctor," rather than in "Animal Doctor," but only at the cost of losing the central thematic link of the story, the permutations on the word hewan (domestic animal).

2. Sepotong cinta--a nice example of the author's inimitable invention of striking "classifiers." He explains: "penolong bilangan dipergunakan dengan pengertian, bahwa tidak ada orang sepanjang sejarahnya pernah mendapat dan memberikan cinta sebagai keseluruhan dan kesatuan sekaligus, kecuali dalam angan-angan." 
of a Dutchman by his maid. The pair got married and were blessed with the three children mentioned earlier.

As it turned out, Corry proved to be a hardworking wife and a devoted farmer, ${ }^{3}$ faithful to her husband, skilled in catering to his wants, as well as shrewd and thrifty in using his money. By the time Jan was born, the family had already managed to buy a Morris. Subsequently they acquired a beautiful house in the Menteng area. Every afternoon swarms of Dutch visitors came to the good veterinarian to have their pets inspected and treated. He drew the line only at monkeys: for one day a German man had brought in a female gibbon, which had repeatedly bitten his thumb while he was inspecting her, and then leapt up and embraced her owner with piercing shrieks. In short, Veterinary Doctor Suharko's earnings flowed in steadily and undisturbed. And not merely his earnings. There were plenty of Dutch married women who brought in their animals simply as pretexts.

In a word, the earnings of the family of Veterinary Doctor Suharko flowed in continuously, without a break. Their furniture was ultramodern, ultraluxurious, and in the latest style. Corry knew how to pick things with simple lines, lines with a classical feel to them, like the contours of her own body.

Then all kinds of disasters happened: the Japanese occupation, the Revolution, the British occupation, the Dutch occupation--all times in which the bourgeoisie were more concerned with the well-being of their own bodies than with that of their pets'. This period, in which the world of the foreign bourgeoisie shriveled up, also shriveled the standard of living of the Suharko family. Short though it was, it proved too long for Corry. During that time she had become too old, ${ }^{4}$ and so she died, leaving behind her husband and her three children.

Nor did the first years of Independence bring much benefit to Veterinary Doctor Suharko. Yet these times, with all their growing difficulties, afforded Suharko beautiful inward memories of his late wife, evoked both in the traces of her handiwork and in the surviving objects she had picked out for their home: the dresser, the sitje, ${ }^{5}$ the grandfather clock, the dining-room table, the Philips drawing-room radio and pick-up, the desk, the cabinets, the earthenware and porcelain vases from Italy and Czechoslovakia, the curtains from the textile mills of Egypt, the leather benches from Morocco, the Japanese hanging scrolls, and the Chinese embroideries. Each object that his wife had bought seemed to say to him: Am I not Corry's choice? And didn't Corry love me well? Each became a place for storing up all his good memories. Long after Corry's death, they continued to be cherished. Even in difficult times, not one of them was ever sold. All this, too, was thanks to Corry's prudent care.

More important than these objects, however, was their eldest son: Jan. His features were so exactly like his mother's--and his manner and conduct no less so.

3. Since we learn two sentences below that Dr. Suharko and his wife will be living in Menteng, the elite residential neighborhood of Jakarta, it may seem odd that Corry is described as a petani. But we will discover later that she kept turkeys in her backyard.

4. "Ia telah menjadi terlalu tua...." The author notes: "terlalu' di sini adalah Indonesia modern, dalam konteks, bahwa masa sulit yang lebih panjang daripada umurnya dapat mengatasinya."

5. Sitje = matching set of table and chairs. According to the author: "Sitje menurut mode yang umum waktu itu adalah satu meja, satu kursi panjang dan 3 kursi untuk satu orang. 
Sometimes, in his relationship with Jan, Suharko forgot that Jan was his son. He carried with him his mother's aura of happiness.

With Corry's death, Indonesian bourgeois values developed apace, without providing any blessings to society. There was little enough work that required his services as a veterinarian in private practice. It was not only that he had aged and was no longer capable of swift and energetic movement: in addition, the condition of society had not yet achieved its set and stable form. In the old days, the Western colonialists and bourgeoisie had always had hobbies to refresh their spirits: above all, their pets. But the national colonialists and bourgeoisie much preferred to immortalize their money in villas, land, and cars; and as hobbies they took human beings as their pets--with all the risks borne by the candidate for petdom.

By sheer chance, he managed, after Independence, to win a good position in a certain government department. A bit later on, he also became active in politics. Finally, he won full control of his department. But in the midst of all these public activities, his heart grew more and more lonely--above all when he was by himself at home, with the children off at school or at play, and his sole companions the furnishings that Corry had left behind.

And so one day he decided to visit his mother in Solo.

Naturally enough, he took his three children along with him. Since converting to Christianity, he'd never dared to face his parents. Indeed, when his father died, he hadn't had the courage to do more than send some money. Even with respect to his mother, he couldn't bring himself to do more than mail a postal order every month. Meet her face to face? He really didn't have the nerve. He was afraid of breaking his mother's heart in her very presence.

But now he had become old. He lived only in his memories. And he clung to each memory of his youth for which he could still grope, to prevent them from disappearing once more: All those passions on plantations out of town! With so many girls! With those clients who brought him their dogs! He realized, of course, that Corry was fully aware of all these goings-on, but kept her silence. Corry herself had once said: No matter how you look at it, men will always be men--even if you give them a whole cartful ${ }^{6}$ of morality and religion every day .

In Solo, his mother, who was now well past old age, also lived in her memories --an imaginary world in which her children were shaped according to her wishes-still fresh, though reality made a mockery of them. The young virgin whom she had once prepared to become her daughter-in-law had long since died, leaving a young virgin daughter behind. And the chickens that she had nurtured for Veterinary Doctor Suharko's wedding had by now probably multiplied a hundredfold and thronged the yard behind her house. Half the chicks died each season, when the pseudopes ${ }^{7}$ struck.

The old woman greeted her aging son with a heart still filled with suspicion. ${ }^{8}$ And her son himself much preferred to live within the splendor of his memories than to deal with his mother's suspicions. Corry the incomparable!

6. Segerobak--another of the author's sharply inventive classifiers.

7. Pseudopes $=$ false plague. What disease is being referred to is not clear. The author writes: "Tentang pseudopest saya tidak dapat temukan kembali catatan saya, ia datang setiap musim pancaroba atau peralihan musim."

8. According to the author: "Curiga, dalam pengertian curiga akan datangnya ungkapan atau pernyataan yang sudah bukan bahasanya dahulu lagi. Bukan soal sex." 
"Lasmi's dead, 'Ko," said his mother. "Her daughter often comes by. She just got back from Europe two months ago, 'Ko; she's been with her father, working at our embassy there in Europe."

Suharko had long since lost interest in petty matters of this kind. So his acquaintance with Kiki, the child of the girl who was once to have been his wife, seemed something of no consequence.

But the confined atmosphere of his provincial home forced him, in spite of himself, to pay some attention to various trivialities. Gradually he began to notice Kiki--a modern girl, with her hair done up in a ponytail. Little by little--and of course without being aware of it--he came under the spell of Kiki's energy, youth, grace, and liveliness. The more the family went on excursions out of town with Kiki, the clearer it became to him that this girl just back from Europe resembled Corry in various ways.

On one excursion to the mountains, he laid his hand as if by accident on the shoulder of the girl who had afforded him a bit of vital energy. Kiki did not resist. And so, timidly, he kissed the girl. Once again, Kiki did not resist.

Out of this came love--which is the same everywhere in the world. Out of this came a life-giving spirit between the love-partners.

A few weeks later, the pair became newlyweds and moved to Jakarta.

Some months after the wedding, Suharko began to realize that little Kiki ${ }^{9}$ was freer, more energetic, and more lively than he had originally observed and judged. His long, slow-moving life became vigorous, energetic, and lively. He noticed how it took little Kiki only a moment to captivate people's hearts with her free ways, her energy, and her liveliness. If his house had once been a kind of besieged fortress, now it was a kind of open field--visitors! Nonstop.

And Veterinary Doctor Suharko began to feel worn out at the sight of all these motley visitors. But little Kiki needed to let her energy, her freedom, and her liveliness flow out to everyone within range. By now Veterinary Doctor Suharko's house had become a lodging-place for hearts young and old who suffered the pangs of loneliness in the midst of the uneasy city of Jakarta.

The result was that Suharko was driven to the margin of his own household.

And he became feeble again--feebler than ever.

And he became lonely again--more lonely than ever.

By now Veterinary Doctor Suharko had no more need of Kiki. All he needed was the integrity of his memories of days gone by. Frequently he would gaze at Jan in silence. Kiki meanwhile had grown into a mature woman. And Suharko couldn't have cared less.

In a short space of time Kiki had "modernized," as she and her set put it, the entire household, and its atmosphere as well. She rearranged the furniture along the lines suggested by the latest women's magazines. The first thing to go was the grandfather clock, which upset her every night by its regular disturbing of her imaginings. She sold it, and bought in its stead a table clock of the latest design. Suharko was naturally taken aback at first to find an object in which Corry had taken such pride sold off without his permission. But he said nothing. With the money she saved up bit by bit Kiki bought decorations for the house which felt very alien to her husband: wire furnishings and maquettes made of clay, velvet,

9. I.e., "si Kiki." 
and rice-straw. ${ }^{10}$ With every day that passed, the realm of Suharko's memories grew more tightly besieged. Each one of Kiki's acts lopped another piece off the world of his memories.

"It's more practical," Kiki would always say, "more modern, and cheaper, too."

In time, the cabinets, with their classical lines and shape, flew away. In their place came cabinets trimmed with steel-and-chrome tubing. ${ }^{11}$ The Philips drawingroom radio, now obsolete and in its dotage, sailed off too, to be replaced by a Grundig stereo. A tape recorder, used only five times, lay sprawled on display in the corner cabinet. Corry's small, unpretentious piano flew away too.

"What do we need a piano for?" she said to Harko one evening. "You don't play yourself, mas, and neither do the children. Anyway, I don't like the piano-or chamber music for that matter. A full orchestra's much better--and that's all it was, one little piano!"

In its place there appeared a 150-cc. Express motorcycle.

"Do look, mas! Doesn't the tank look elegant? How stupid people are to buy Puches--they're just like jarankepang." 12

And on this motorcycle Kiki went roaming every day: to buy flowers or saté, to go shopping in Pasarbaru, ${ }^{13}$ or to go to the movies. On the $150-\mathrm{cc}$. Express she felt herself an advanced, modern woman, and: eye-catching to the men. She enjoyed catching men's eyes.

"This way, mas, I don't need to bother you by asking to borrow the car."

In the course of all this, the memory-world of Veterinary Doctor Suharkso was destroyed, to become no less late than the late Corry herself. With each day Corry became more a blur, looming up and disappearing unpredictably. And he observed that his own children were increasingly becoming strangers in their own home, shoved aside by visitors who, in their loneliness, longed to taste Kiki's energy, freedom, and liveliness.

One day, when Suharko came back from inspecting an epidemic of foot-andmouth disease that was ravaging the countryside, and rain had fallen unexpectedly, he discovered Kiki entertaining a guest--a young lodger from the house next door.

10. The author notes: "Pada awal tahun 50-an perabot dari kawat merupakan pesona baru, setelah sejak pendudukan Jepang sampai akhir masa revolusi orang tak lagi melihat barang-barang dari kawat. Semasa Jepang, benda-benda dari logam, terutama baja dan besi, dituntut oleh Jepang untuk diserahkan. Pada umumnya berbentuk tenunan harmonika. Untuk tempat lampu, tempat koran, keranjang, rak perabot dapur, dengan atau tanpa kombinasi dengan pipa besi kecil. Maquet, memang model kecil rumah atau kapal layar. Beledu dan jerami untuk kulit."

11. The printed text has: ". . staalbuis ber-kroon diplitur putih." The author writes: "Staalbuis, pipa baja. Berkroon, harusnya: berkroom. Diplitur, rasanya ditambah oleh korektor [proofreader]. Bila pipa baja dikroom dengan sendirinya menjadi putih."

12. Jaran kepang, Javanese for kuda kepang, wickerwork "hobbyhorses" held between the legs and used for various folk performances.

13. In the 1950s Pasarbaru was the smartest shopping center in Jakarta. 
What's he doing here? And why him? And all the rest of them? They're surely not here to see me?

These questions brought Suharko face to face with an accusation he had never before experienced: You're jealous! Jealous!

A few hours later, Kiki said to him: "Mas, I'm off. I want to trade this motorcycle in for a better one."

And the 150-cc. Express put-putted in the yard, then roared off, to be swallowed up in Jakarta's night traffic. At two o'clock in the morning, Kiki returned. With the 150-cc. Express. Suharko himself got up to let her in. The old man felt that he had no choice but to let her go her way. He had enjoyed Kiki's youth. Didn't she too have the right to enjoy her own youth? That night he couldn't sleep a wink. Kiki, however, sank into a deep, contented slumber. Suharko observed-now for the first time!--Kiki sprawled on her back beside him: her eyes partly open, her mouth agape, the points of her teeth in a horrifying row, and the sharp curve of her upward-pointing lips. He felt himself couched beside a lioness. He felt himself couched beside a crocodile. He felt himself couched with a creature that made his flesh crawl. He sprang out of bed, whispering to himself:

"I'd never have guessed that a human being could be so like an animal! "14

Slowly he walked out to the front yard, sat down in a garden chair, and reflected on his children's future--reflected too on Corry, who had brought with her a farm-like atmosphere. Yet now the turkey-coops behind the house had been eliminated to make way for a badminton court. And the low console wall, which Corry had once decorated with artificial flowers, ${ }^{15}$ and where the family had been accustomed to take the air while watching the passing traffic, was now cluttered with a glass tank filled with ornamental fish: goldfish, spadefish, moonfish, eels, and starfish. ${ }^{16}$

Usually by five in the morning his eldest child, Jan, was already up and doing his exercises. Yes. He heard the side door being opened. He heard his son come out. And he heard the boy stumble and fall, colliding with something hard. He saw his son sprawled unconscious beneath the 150-cc. Express, his forehead split open by the rim of the foot-rest. The blood gushed out without stopping. Suharko dragged Jan to a sofa, laid him out on it, and began to treat him.

When Kiki awoke and saw her stepson swathed in bandages, and the pillows and cover of the sofa drenched with blood, annoyance etched itself clearly on her face.

"Why let the blood dribble all over the sofa? Why not on the floor?"

For the first time in her married life Kiki was answered with the blow of a stick ${ }^{17}$ in her face. And Suharko roared:

14. Not binatang, but hewan.

15. According to the author, the printed text, which has "bunga-bungaan," is in error; the word should be "bunga-bunga, artinya bunga palsu."

16. The author identifies these as follows: maskoki = Carassius auratus; maanvis = Platax pinnatus; plati (the printed text incorrectly has plastik) $=$ Xiphophorus maculatus; ikan ular = Anguilliformes; and bintang = Asterias amurensis.

17. Kiki dijawab dengan rotan pada mukanya. The author explains: "Bukan tongkat untuk jalan-jalan. Dalam rumahtangga Indonesia di kota biasa terdapat apa yang dinamai 'bulu ayam,' alat penghapus debu dari bulu ayam yang dirangkai dengan benang dan dililitkan pada sebatang rotan kecil. Dalam kehidupan rumah- 
"Get rid of that Express! If you won't do it, I'll throw it out myself!"

From then on the 150-cc. Express stayed put beside the house, with oil oozing out around it. And every time suharko returned from work and saw the motorcycle still there, he struck his wife with the stick. For a whole week, he continued to strike Kiki in the face. Meantime, Jan was scarred for life. dealer. ${ }^{18}$

The relationship between Kiki and Suharko was like that between goat and

Of course Kiki eventually asked for a divorce.

"Of course," said Suharko, "and take all these modern things with you. But you've got to return all of Corry's furniture. Take all the money there is and get going."

After that day Kiki left her house and husband. She'd hunt for the things she'd once sold. And with each one she retrieved, she'd provide an IOU in the name of Veterinary Doctor Suharko. Then she'd sell what she'd retrieved to someone else. And so on, and so on. Only one thing she wouldn't sell: the 150-cc. Express. But in the end that was sold too. I was the first to buy it. But I knew her methods only too well. So I refused her IOU."

"Of course your story isn't all true?" said my friend to his friend.

"Of course not. Part of it, of course, is my own fantasy."

"And what's the point of the fantasy?"

"So you can get a clearer picture."

With that we went home. I sat behind my friend on the motorcycle he had just bought.

And in fact, a month later, my friend received a visit from the woman who went by the name Kiki in my friend's friend's story. In floods of tears she detailed the torments of her domestic life. She asked for the return of the 150-cc. Express since her husband demanded it. And she was afraid of her husband.

In that moment my friend felt compelled not to believe the story of my friend's friend. Tears were sufficient evidence of sincerity. He turned over the motorcycle and accepted the IOU.

Since that day, the woman whom my friend's friend called Kiki has never showed her nose again.

tangga bila dikatakan dipukul dengan rotan maka asosiasi orang akan segera berpaut dengan tangkai 'bulu ayam' tsb., karena alat ini dapat dikatakan pasti ada dalam keluarga kota."

18. Seperti kambing dengan makelarnya. According to the author, "makelar di sini adalah broker, yang ingin segera terlepas dari sesuatu dengan keuntungan." 